\title{
NATIVE SPEAKER AND CULTURAL AUTHENTICITY IN EFL CLASS: A LINGUISTIC ANTHROPOLOGY PERSPECTIVE
}

\author{
I Komang Budiarta \\ English Education Study Program, Faculty of Teacher Training and Education \\ Mahasaraswati Denpasar University \\ Email:mrbudi@unmas.ac.id
}

\begin{abstract}
In Bali, there are many schools that combine national and international curriculum, English is used as a medium of instruction. Moreover, English as a foreign language (EFL) is considered an important subject. Thus, these schools try to design the teaching-learning process that emphasizes language and its culture. After doing the library research by reviewing some related textbooks and research articles, this conceptual article figured out that the ideas of involving a native speaker and cultural authenticity in teaching EFL classes should be based on the learning objective. Both are important if the focus of the EFL class is put toward giving students a contextual experience of EFL use. However, if it is primarily intended to make the students experience the real cultural contexts of English, the ideas of involving the native speaker and cultural authenticity might be irrelevant. This might happen because teaching nowadays is intended to provide students to deal with the $21^{\text {st }}$ century so that they should experience different cultural contexts that enable them to collaboratively work. To summarize, a native speaker and cultural authenticity are important in EFL class; however, they should not be used as a basic assumption of the success and failure of EFL class.
\end{abstract}

Keywords: Native Speaker, Cultural Authenticity, EFL Class, and Linguistic Anthropology

\begin{abstract}
ABSTRAK
Di Bali, terdapat banyak sekolah yang menggabungkan kurikulum nasional dan internasional dan bahasa Inggris digunakan sebagai media pengajaran. Selain itu, bahasa Inggris sebagai bahasa asing (EFL) dianggap penting. Oleh karena itu, sekolah-sekolah ini mencoba mendesain proses belajar mengajar yang menekankan tidak hanya bahasa tetapi juga budayanya. Setelah melakukan penelitian kepustakaan dengan mereview beberapa buku teks dan artikel penelitian terkait, artikel konseptual ini akhirnya menemukan bahwa ide-ide yang melibatkan penutur asli dan keaslian budaya dalam pengajaran di kelas EFL harus didasarkan pada tujuan pembelajaran. Penutur asli dan keaslian budaya penting jika fokus kelas EFL ditujukan untuk memberi siswa pengalaman kontekstual penggunaan EFL. Namun, jika ini dimaksudkan untuk membuat siswa mengalami konteks budaya bahasa Inggris, ide-ide yang melibatkan penutur asli dan keaslian budaya mungkin tidak relevan. Hal ini mungkin terjadi karena mengajar siswa untuk abad ke-21 harus memberikan kesempatan kepada siswa untuk mengalami konteks budaya yang berbeda sehingga mereka mampu bekerja secara kolaboratif. Penutur asli dan keaslian budaya penting dalam kelas EFL. Namun mereka tidak boleh digunakan sebagai asumsi dasar keberhasilan dan kegagalan dalam kelas EFL.
\end{abstract}

Kata kunci: Penutur Asli, Keaslian Budaya, Kelas EFL, dan Linguistik Antropologi

\section{INTRODUCTION}

Language as a means of communication is always interesting to be discussed. The discussion of language can be seen from many different perspectives. The language itself can be interdisciplinary so that it can be learned as a new perspective of combining language and other scopes of study. Psycholinguistics, for example, tries to view language in accordance with psychology and linguistics. On the same ideas, linguistic anthropology tries to study language and anthropology or culture. There are many perspectives that could be studied in one of the interdisciplinary branches of linguistics, linguistic anthropology. 
The particular approach that studies the relationship between language, thought, and culture is known as anthropological linguistics. Known variously as ethnolinguistics, cultural linguistics, or linguistic anthropology, anthropological linguistics is a branch of both anthropology and linguistics (Danesi, 2004). The goal of anthropological linguistics is to study languages by gathering data directly from native speakers. Known as ethnography or participant observation, the central idea behind this approach is that the linguist can get a better understanding of a language and its relation to the overall culture by witnessing the language used in its natural social context. It is then of necessary in studying linguistics which is related to the use of language in its cultural contexts.

The terms linguistic anthropology and anthropological linguistics are currently understood in a variety of ways. These two terms are interchangeably used to refer to the study of language in cultural contexts. In addition, the terms have already become underlying theoretical foundations which strengthens how the language should be seen in doing a study in relation to linguistic anthropology. Duranti (1997) mentions that "linguistic anthropology" over both "anthropological linguistics" and "ethnolinguistics" is part of a conscious attempt at consolidating and redefining the study of language and culture as one of the major subfields of anthropology. This view of the field was clearly stated by Hymes in Duranti (1997) when he defines it as the study of speech and language within the context of anthropology.

Furthermore, there are many definitions that are simply stated to define linguistic anthropology; they try to define it as crystal clear as possible. Linguistic anthropology goes beyond analyzing the structure and patterning of language (a central focus of linguistics) to examine the contexts and situations in which language is used (Ottenheimer, 2013). He clearly mentions that linguistic anthropology is more than analyzing language structure and pattern which is used as the central focus of the language. It is comprehensively used to examine the context and situations in which the language is used as a means of communication. In other words, linguistic anthropology mainly focuses on language as a major component in carrying out a study or analysis in linguistic anthropology.

Scupin \& DeCorse (2016) clearly defines that linguistic anthropology focuses on the relationship between language and culture, how language is used within society, and how the human brain acquires and uses language. They argue that when the focus is put forward to studying both language and the cultural contexts where the language is used; it is the domain of linguistic anthropology. This new branch of linguistic perspective becomes widely adopted in many studies of language. The linguist who deals with anthropology as the ideas of their study also develops rapidly as it is very interesting to do.

Since the emergence of linguistic anthropology, it is considered one of the important parts of language study. Linguistic anthropology is simply stated as the study of language as a cultural resource and speaking as a cultural practice (Duranti, 1997). This clearly states that linguistic anthropology is mainly focused on studying the language as it is used in its 
cultural context. In other words, language is the center of the study in linguistic anthropology. This understanding should be owned by those who involve in the teaching-learning process especially language as the center of a discussion that delivers in different cultural contexts. For instance, English in Indonesia is considered as a foreign language. Thus, delivering language as a foreign language in the Indonesian cultural context needs further comprehensive understanding.

As a result, the idea of involving native speakers in language teaching and learning process becomes an interesting phenomenon that might give the cultural context of using English as a foreign language. The discussion of the native and non-native speakers is not really practical, nor is it really theoretical; besides, it is popular in language teaching (Phillopson and Riley in Jufrizal, 2018). This signifies that the involvement of native speakers in language teaching becomes wide-spread discussion all over the world including Indonesia. the roles of native speakers in English language teaching can bring beneficial impact to the teaching and learning process not only specific on language teaching but also other subjects.

In Indonesia, English is categorized as a foreign language; consequently, the teaching-learning process is also differently designed. The ideas of involving English native speakers for the sake of transferring cultural authenticity to the students are widely spread in many schools in Indonesia. The involvement of English native speakers in the teachinglearning process of English as a foreign language (EFL) is also expected to improve the students' English language proficiency so that they can learn or master the language as well as the native speakers. English native speaker is assumed to be able to deliver English as a foreign language much better than those who are considered as English non-native speaker. However, this idea is still debatable as the English native speaker may know English cultural authenticity.

In line with the background which has been previously elaborated, the present research is limited on reviewing linguistic anthropology perspectives of teaching English as a foreign language and its relationship on the roles of a native speaker and cultural authenticity. This research is mainly done by reviewing some related literature in accordance with the research problems which are studied in this library research. Furthermore, this research is intended to answer the research problems which have been previously formulated. The research problems are as follows: what are the roles of a native speaker and cultural authenticity in EFL class? And how do native speakers and cultural authenticity affect EFL class?

The present research is carried out to figure out the scientific answers to the research problems. Stating the clear and reachable purpose of scientific research is important to direct the research and to give a scientific map. Generally, the purpose of the present study is to review the ideas of involving the native speaker and cultural authenticity in the EFL class based on the perspective of linguistic anthropology. Besides the general-purpose, the specific purposes of the present study were to figure out to know the roles of native speaker and cultural authenticity in EFL class and how native speaker and cultural authenticity affect EFL class.

\section{METHOD}


The present article is presented in the form of a Conceptual Article. It is the research article that aims at doing a deep study of the researcher's concept of a problem that is discussed by examining relevant sources. Therefore, the method used in writing this conceptual article is the library research method. To produce a qualified conceptual article, the researcher first conducted a study of sources that are relevant to the problem, both in line with and in conflict with the concept of the study. This literature source is important to provide a deeper study of the problems taken. The relevant sources are important to give a much deeper understanding concerning the topic to be discussed in the present conceptual article.

Sources that are used as reference materials to produce qualified conceptual articles are articles that are relevant to the problem being studied, the results of previous research, and theories that can be explored and studied from textbooks. The most important part of a conceptual article is the writer's opinion or position on the matter discussed. It was developed from an analysis of thoughts about the same problem and has been published. The conceptual article is thus not just quotations from a number of similar articles or copies of writings from a number of sources, but the results of the study also show the concepts of critical thinking of the researcher in synthesizing the concepts.

\section{DISCUSSION}

\section{Native Speaker}

In Indonesia, English is considered a foreign language. As a foreign language, of course, Indonesian are categorized as English non-native speakers. Thus, how the language should be delivered in EFL contexts should be a different state. Stern (1991) clearly mentions that a native speaker's language proficiency implies the ability to act as a speaker and listener in diverse ways. The intuitive mastery that the native speaker possesses to use and interpret language appropriately in the process of interaction and in relation to social context. Thus, native speakers in English language teaching might bring different learning atmosphere.

In addition, Richards \& Schmidt (2002) states that a native speaker is a person who learns a language as a child and continues to use it fluently as a dominant language. Native speakers are said to use a language grammatically, fluently and appropriately, to identify with a community where it is spoken, and to have clear intuitions about what is considered grammatical or ungrammatical in the language. In other words, they can perform much better than others. In some contexts (the teaching of some languages in some countries) it is taken as a basic assumption that the goal of learning a second or foreign language is to approximate as closely as possible to the standards set by a native speaker.

In this context, competence describes the capacity for language, that is, the knowledge- mostly unconscious-that a native speaker has of the principles that allow for the interpretation and use of a particular language (Duranti, 1997). Since the native speaker has intuitive both language and cultural knowledge, they tend to be very flexible in dealing with language use. The native speaker could teach the language from many perspectives especially when they use the language. The rich understanding of both language and cultural knowledge might be obtained 
by the students. As what has been mentioned by Stern (1991) that a language is what its native speakers say, not what someone thinks they ought to say.

Furthermore, it is arguable that native speakers of English can no longer make strong proprietary claims to the language which they now share with most of the developed world (Broughton, Brumfit, Flavell, Hill, \& Pincas, 2003). Stern (1991) states that a native speaker is of course at home in various styles, registers, or domains. Collectively the different varieties of language may be looked upon as different codes; in analogy to bilingualism, it is reasonable to describe native speakers who master more than one such code. In addition, Walkinshaw \& Duong (2012) mention in their research that pronunciation becomes an advantage of learning from a native English speaker.

Some research findings clearly showed that non-native students preferred to be taught an English native speaker. When native English speakers display mindfulness (i.e. being aware of multiple contexts of intercultural communication), they could identify the success or failure of the communication is contingent on the interaction between the speakers (Young \& Faux II, 2011). On the other hand, Kosar (2018) figured out that students tended to choose both native and nonnative English speakers as native speakers were good at teaching speaking, pronunciation, and target culture, whereas non-native speakers were good at teaching grammar, reading, and writing.

However nowadays paradigm of the teaching-learning process of English as a foreign language has shifted the roles of native speakers. McKay in Tan, Farashaiyan, Sahragard, \& Faryabi (2019) stated focusing on native speakers in language teaching is not the only way nowadays in order to obtain an accurate portrait of how English is used for diverse objectives in numerous intercultural communication among EFL learners. It means that cultural authenticity should be exposed; however, intercultural competence should not be neglected.

\section{Cultural Authenticity}

Dealing with language learning, particularly English as a foreign language cannot be separated from its cultural context. Ottenheimer (2013) also mentions that cultural emphasis an important aspect of a culture, often reflected in the vocabulary the culture's members speak. In linguistic anthropology, language and culture are respective topics that should be learned by the students in order to improve their language proficiency. Understanding the language culture enables students to get more understanding concerning the language and the culture as well so that they are inseparable during the teachinglearning process.

In addition, cultures and languages do not exist in isolation, nor are they unchanging (Foley, 1997). As a foreign language in Indonesia of course, contextually it might be different even though every culture has cultural universal that is characterized by essential behavioral characteristics of humans found in all societies (Scupin \& DeCorse, 2012) and different (Ottenheimer, 2013). Thus, in teaching a language, teachers need to consider cultural contexts where the language is going to be used by language learners. This might avoid misunderstanding when they put the language into practice contextually.

Nieto (2010) argues that culture is created and socially constructed is the fact 
that it is learned. In other words, culture is not handed down through our genes, nor is it inherited. In addition, Scupin \& DeCorse (2016) cultural knowledge is gained through enculturation; enculturation is a lifelong process, and it links individuals with the specific culture to which they are exposed. Immediately after they are born, infants begin to absorb their language and culture-the etiquette, mores, values, beliefs, and practices of their societythrough both unconscious and conscious learning-situational, social, and symbolic.

Culture plays an instrumental role in shaping speakers' communicative competence, which is related to the appropriate use of language (e.g., how native speakers make an apology and what kind of form the apology takes) (Richards \& Renandya, 2002). In other words, it is defined by the shared social and cultural conventions of a particular group of speakers. Therefore, it is essential to recognize different sets of culturally determined rules in communication. It signifies that language and culture are inseparable in the teaching-learning process of English as a foreign language.

As what has been aforementioned, teaching students of EFL class should be designed as close as possible with the cultural context of English. As we noted earlier, cultural authenticity involves examining the connections between social practice and the central code of culture. cultural authenticity can be defined as whether or not a book reflects those values, facts, and attitudes that members of a culture as a whole consider worthy of acceptance or belief (Fox \& Short, 2003). Thus, cultural authenticity becomes an integral part of English language learning, for this context will give students further enlightenment of how English is contextually used in their communicative environment.

Richards \& Schmidt (2002) also emphasize that in the teaching-learning process, cultural literacy or familiarity with cultural and other types of knowledge regarded as necessary for informed participation in a nation or culture. They add that there are often more problems in cross-cultural communication than in communication between people of the same cultural background. Cultural literacy may or may not be something possessed by a person who is bilingual. It is in line with Wang (2018) who summed up, the lack of cultural awareness and insufficient background knowledge directly hinders students' comprehension and linguistic competence to a large extent. In order to improve students' linguistic competence, their cultural awareness needs to be enhanced urgently.

In addition, Mao (2009) considers that students who deal with intercultural communication with native English speakers might not succeed in carrying out a conversation if the topic of discussion is specifically about the culture of the English. Aside from the condition that language-oriented teaching contributed influence on native speakers' cultural acquisition by immersion, the use of authentic English materials, which were assumed to be related with the English language spoken and written by mere English native speakers, also increasingly supported the immersion of inner circle people's culture (Morganna, Sumardi, \& Tarjana, 2018).

The roles cultural authenticity of English contexts nowadays are not the main focus of EFL class because the teaching-learning process is mainly intended to provide students with $21^{\text {st }}$ - 
century life skills in which they are required to be collaborative with people all over the world. Chinh (2013) also mentions that rather than relying on the paradigm of native-speaker competence and target culture, the culture teaching in ELT now aims at cultural diversity to develop learners as intercultural speakers in a globalized context. Moreover, learners who seem to learn English for instrumental purposes as a tool to utilize in crosscultural settings, the need to learn the native speaker culture seems quite oldfashioned (Coskun, 2010).

\section{The Perspective of Native Speaker and Cultural Authenticity in EFL Class}

Indonesia, particularly Bali, has a lot of schools that combine both national and international curriculum. Thus, these schools make use of English as a medium of instruction in the teaching-learning process. This situation also puts English as an important subject to be taught at schools. In the EFL class, the ideas of involving English native speakers in order to make students experience cultural authenticity become commonly used model. Ahearn (2017) states that from the perspective of linguistic anthropology, it is most essential to study literacy practices on the ground and in actual social settings.

Furthermore, Kramsch (2014) elaborates that as long as culture acquisition only means the ability to momentarily see the world through the eyes of a native speaker or to occasionally behave in ways that conform to native speaker expectations, culture acquisition should be a desirable goal of language learning. Brown (2007) also adds that while most learners can indeed find positive benefits in cross-cultural living or learning experiences, a number of people experience psychological blocks and other inhibiting effects of the second culture. Cross-cultural learning can be best achieved with native speakers.

Learning EFL, that is, English in one's native culture with few immediate opportunities to use the language within the environment of that culture enables students to learn comprehensively both the language and the culture of the language. However, Brown (2000) also adds that the question of whether or not to distinguish between native and non-native speakers in the teaching profession has grown into a common and productive topic of research in the last decade. For many decades the English language teaching profession assumed that native English-speaking teachers, by virtue of their superior model of oral production, comprised the ideal English language teacher (Walkinshaw \& Duong, 2012 and Kosar, 2018).

A number of recent research studies have shown the positive effects of incorporating cultural awareness in language classrooms (Byram \& Feng in Brown, 2000). Cultural awareness should be carefully built-in language EFL class as they will deal with this soon after they use the language in interactional communication. Besides, Nieto (2010) adds that culture is learned is also apparent in the very concept of biculturalism. Bilingual education, for instance, very often is called bilingual/bicultural education because it is based on the principle that one can learn two languages and two cultural systems in order to function and even to succeed in different linguistic and cultural contexts.

Kramsch (2002) states that language socialization has the double function of learning to understand language through social experiences and of 
learning to understand social experiences through language. It is through the everyday language practices of social life that children become part of a community. The child is viewed as an active agent in this new conception of enculturation and learns to choose and design appropriate responses to specific social situations and contexts as he or she is exposed to them. Psychological anthropologists are contributing to a better understanding of how children acquire cultural knowledge through exposure and active participation in everyday social interaction (Scupin \& DeCorse, 2016).

In addition to these ideas, Nieto (2010) mentions that the role of the teacher as a cultural accommodator and mediator is fundamental in promoting student learning. In much of the research reviewed, it has become apparent that teachers have a great deal to do with whether and how students learn. Consequently, teachers' role as cultural mediators in their students' learning becomes even more urgent. Teachers need to support this kind of learning while at the same time affirming the cultures and languages that children bring to school as viable and valuable resources for learning.

The teaching of culture both within and beyond language should be considered as an integral part of teaching English as a foreign language (Mao, 2009). Thus, the teaching syllabus should give more emphasis on intercultural rather than only cultural knowledge. Besides, de Bot, Ginsberg, \& Kramsch (1991) claim that the efforts made to define and measure cultural proficiency bring to light some of the major current obstacles to the integration of language and culture in the teaching of foreign languages.
Furthermore, by proposing the proper English standard on the basis of native speakers' cultures, or in other words the English dialects used by inner circle people, it would then be English native speakers' cultures that were invariably nuanced in EFL learning (Morganna et al., 2018). On the other hand, Wang (2018) states that it is generally agreed that what helps in a cultural acquisition is first and foremost personal contact with native speakers. However, this should not be overgeneralized as in teaching EFL classes.

The debate whether involving native speakers or non-native speakers for the sake of exposing cultural authenticity of the language is no longer relevant as students should be exposed to different cultural contexts for their future lives. The students recently should be exposed to various cultural contexts in order to make them well prepared for their future lives. In other words, they should experience different cultural contexts in the EFL class (Chinh, 2013 and Coskun, 2010). To sum up, native speakers and cultural authenticity are important in EFL classes; however, they are not the main reason for the successful EFL class.

\section{CONCLUSION}

The idea of involving the native speaker and cultural authenticity in teaching EFL classes should be based on the objective of learning. If the main focus is merely to provide the students with the contextual experience of EFL use, the native speaker and cultural authenticity are important. However, if the primary objective is to enable the students to experience the real cultural contexts of English, the ideas of involving the native speaker and cultural authenticity might no 
longer be relevant. This might happen because teaching nowadays is mainly intended to provide students to deal with the $21^{\text {st }}$ century so that they should experience different cultural contexts that enable them to collaborative work in this shared world. Both of them, native speakers and cultural authenticity, are important in EFL class; however, they should not be used as a basic assumption of the success and failure of EFL class.

\section{REFERENCES}

Ahearn, L. M. (2017). Living Language: An Introduction to Linguistic Anthropology (2nd ed.). West Sussex: John Wiley \& Sons Ltd.

Broughton, G., Brumfit, C., Flavell, R., Hill, P., \& Pincas, A. (2003). Teaching English as a Foreign Language (2nd ed.). New York: Taylor \& Francis Group.

Brown, H. D. (2000). Principles of Language Learning and Teaching (4th ed.). White Plains, NY: Addison Wesley Longman Inc.

Brown, H. D. (2007). Principles of Language Learning and Teaching (5th ed.). White Plains, NY: Pearson Education, Inc.

Chinh, N. D. (2013). Cultural diversity in english language teaching: Learners' voices. English Language Teaching, 6(4), $1-7$. https://doi.org/10.5539/elt.v6n4p1

Coskun, A. (2010). Whose English should we teach? Reflections from Turkey. ESP World, 9(1), 1-20.

Danesi, M. (2004). A Basic Course in Anthropological Linguistics. Ontario: Canadian Scholars' Press Inc.

de Bot, K., Ginsberg, R. B., \& Kramsch, C. (Eds.). (1991). Foreign Language Research in Corss-cultural perspective. Amsterdam: John Benjamins Publishing Company.

Duranti, A. (1997). Linguistic Anthropology. Cambridge:
Cambridge University Press.

Foley, W. A. (1997). Anthropological Linguistics: An Introduction. Malden: Blackwell Publishers Ltd.

Fox, D. L., \& Short, K. G. (Eds.). (2003). Stories Matter: The Complexity of Cultural Authenticity in Children's Literature (review) (Vol. 30). https:// doi.org/10.1353/chq.2005.0027

Jufrizal. (2018). Anthropological Linguistics: An Introduction for Beginners. Yogyakarta: Graha Ilmu.

Kosar, G. (2018). Turkish Tertiary Level EFL Students' Perceptions of Native English-Speaking Teachers and NonNative English-Speaking Teachers. European Journal of English Language Teaching, 4(1), 96-119. https://doi.org/10.5281/zenodo.14283 60

Kramsch, C. (Ed.). (2002). Language Acquisition and Language Socialization. London: Continuum.

Kramsch, C. (2014). Language and Culture. AILA Review, 27(2), 30-55. https://doi.org/10.1075/aila.27.02kra

Mao, W. (2009). Teaching Culture Within and Beyond Language. English Language Teaching, 2(4), 144-148. https://doi.org/10.5539/elt.v2n4p144

Morganna, R., Sumardi, \& Tarjana, S. S. (2018). Immersion vs construction: The portrayals of culture in Indonesian EFL learning paradigm. Journal of Language and Linguistic Studies, 14(2), 283-304.

Nieto, S. (2010). Language, Culture, and Teaching: Critical Perspective. New York: Routledge.

Ottenheimer, H. J. (2013). The Anthropology of Language: An Introduction to Linguistic Anthropology. Belmont: Wadsworth Cengage Learning.

Richards, J. C., \& Renandya, W. A. (Eds.). (2002). Methodology in Language Teaching: An Anthology of Current Practice. Cambridge: Cambridge University Press.

Richards, J. C., \& Schmidt, R. (2002). 
Longman Dictionary of Language Teaching and Applied Linguistics (3rd ed.). London: Pearson Education Limited.

Scupin, R., \& DeCorse, C. R. (2012). Anthropology: A Global Perspective (7th ed.). Boston: Pearson.

Scupin, R., \& DeCorse, C. R. (2016). Anthropology: A Global Perspective (8th ed.). New York: Pearson Education, Inc.

Stern, H. H. (1991). Fundamental Concepts of Language Teaching. Oxford: Oxford University Press.

Tan, K. H., Farashaiyan, A., Sahragard, R., \& Faryabi, F. (2019). Implications of English as an international language for language pedagogy. International Journal of Higher Education, 9(1), 22-31.

https://doi.org/10.5430/ijhe.v9n1p22
Walkinshaw, I., \& Duong, O. T. H. (2012). Native- and Non-Native Speaking English Teachers in Vietnam: Weighing the Benefits. The Electronic Journal for English as a Second Language, 16(3).

Wang, G. (2018). On the Strategies of Enhancing Students' Cultural Awareness in College English Teaching. English Language Teaching, 11(12), 116. https://doi.org/ 10.5539/elt.v11n12p116

Young, R., \& Faux II, W. V. (2011). Descriptions of difficult conversations between native and non-native english speakers: In-group membership and helping behaviors. The Qualitative Report, 16(2), 494508. Retrieved from http://www.nova.edu/ssss/QR/QR162/young.pdf 